\title{
Table of Contents from the Gesamtausgabe Edition
}

Page numbers refer to the Niemeyer pagination, followed by the pagination of this translation.

\section{CHAPTER ONE}

\section{The Fundamental Question of Metaphysics}

$\S_{I}$. The question that is first in rank because it is broadest, deepest, and most originary: "Why are there beings at all instead of nothing?" (I/I)

$\$ 2$. The asking of the question that is first in rank as philosophy. Two misunderstandings of the essence of philosophy (6/9)

$\$ 3$. The inception of questioning about beings as such and as a whole among the Greeks, guided by the fundamental word phusis (10/14)

$\$ 4$. The question that is first in rank as the fundamental question of metaphysics. Introduction to metaphysics as leading into the asking of the fundamental question. The conscious ambiguity of the title of the lecture course (I3/I9)

\$5. The development of the question, "Why are there beings at all instead of nothing?" ( $15 / 23)$ 
a) The questioning attitude as willing to know ( $15 / 23)$

b) The linguistic formulation of the interrogative sentence. The break in the question and the suspicion against the "instead of nothing" (17/25)

c) The linguistic formulation of the question as respect for tradition (I8/27)

\$6. The question of Being and "logic." True speaking of Nothing in thinking and poetry ( $19 / 28)$

$\$ 7$. The elucidation of the abbreviated question in contrast to the complete question. The "instead of nothing" makes beings waver $(2 \mathrm{I} / 3 \mathrm{I})$

$\$ 8$. Questioning as opening up the domain of the proper questionability of beings: their oscillation between not-Being and Being (22/33)

\$9. The twofold meaning of the term "being." The apparent superfluity of the distinction between Being and beings and the ambiguity of the "fundamental question" as a question about the ground of Being (23/34)

§IO. The development of the prior question: "How does it stand with Being and with our understanding of Being?" (25/36)

III. The more precise determination of the question: "How does it stand with Being? Is Being just the sound of a word or is it the fate of the West?" (28/4I)

\$I2. Clarification of the fact: Being a word-vapor! The question of Being and "ontology" $(30 / 43)$

$\$_{13}$. Elucidation of the relation between the fundamental question of metaphysics and the prior question: the new concept of the prior question - the question that runs ahead and is thus historical through and through $(32 / 46)$

\$I4. Philosophy and "the science of history" (33/47)

\$15. The inner belonging of the intrinsically historical asking of the question of Being to the world history of the earth. The concept of spirit and its misinterpretations (34/49)

\$I6. The factuality of the fact of the oblivion of Being as the real ground for our misrelation to language $(38 / 55)$ 
xxxviii - Table of Contents from the Gesamtausgabe Edition

CHAPTER TWO

On the Grammar and Etymology of the Word "Being"

$\$_{17}$. The illumination of the essence of Being with regard to its essential link to the essence of language $(40 / 57)$

A. The Grammar of the Word "Being"

$\$_{18}$. The form of the word "Being": verbal substantive and infinitive $(42 / 59)$

\$19. The infinitive $(43 / 6 \mathrm{I})$

a) The origin of Western grammar in the Greek meditation on Greek language: onoma and rhèma (43/6I)

b) The Greek understanding of ptōsis (casus) and enklisis (declinatio) (45/64)

$\$ 20$. The Greek understanding of Being: Being as constancy in the double sense of phusis and ousia (45/64)

$\$ 2$. The Greek understanding of language (49/70)

a) The infinitive as no longer manifesting what the verb otherwise reveals $(49 / 7 \mathrm{I})$

b) The infinitive of the Greek word einai (52/74)

c) The fixing and objectification of the most general emptiness $(52 / 75)$

B. The Etymology of the Word "Being"

$\$ 22$. The three stems of the verb "to be" and the question of their unity $(54 / 77)$

$\$ 23$. The result of the twofold elucidation of the word "Being": the emptiness of the word as blurring and blending $(56 / 80)$

CHAPTER THREE

The Question of the Essence of Being

$\$ 24$. The unavoidable fact: understanding Being yet not understanding it $(57 / 82)$

$\$ 25$. The uniqueness of "Being," comparable only to Nothing $(58 / 83)$ 
\$26. The "universality" of "Being"; "beings" as "the particular." The necessary priority of the understanding of Being (60/87) \$27. The fundamental attempt. The understanding of Being as indispensable: no saying without the understanding of Being, no human Being without saying (62/89)

$\$ 28$. The understanding of Being as "ground" of human Dasein $(63 / 90)$

$\$ 29$. The understanding of Being and Being itself as the question that is most worthy of all questioning. The question of the meaning of Being (63/9I)

$\$ 30$. Review of the preceding discussion: the decisive step from an indifferent fact to the happening that is most worthy of questioning $(64 / 93)$

$\$ 3$ I. The distinction of the word "Being" in contrast to all words for "beings": the more essential directedness of Being and word to each other $(66 / 95)$

$\$ 32$. The distinct definiteness of our understanding of Being and its arrangement enjoined by Being itself. The "is" in various examples $(67 / 97)$

\$33. The manifold sense of the "is." The understanding of Being on the basis of the "is" in the sense of constant presence (ousia) (69/99)

CHAPTER FOUR

The Restriction of Being

$\$ 34$. The formulaic ways of saying Being in distinctions (Being and ...) (7I/102)

$\$ 35$. The seven guiding principles regarding the distinctions of Being from some other $(7 \mathrm{I} / \mathrm{IO} 3)$

\section{A. Being and Becoming}

$\$ 36$. Being as opposed to becoming. Parmenides and Heraclitus: Being - the inner perdurance of the constant that is gathered in itself ( $73 /$ IO5) 


\section{B. Being and Seeming}

$\$ 37$. The self-evidence and ordinariness of this distinction-the lack of understanding of its original separation and its belonging together. Three ways of seeming (75/107)

$\$ 38$. The inner connection between Being and seeming. "Being" understood in the Greek way as phusis: the emerging, abiding sway and the appearing that seems (76/110)

\$39. The unique, essential connection between phusis and ale theia - truth as belonging to the essence of Being (77/III)

$\$ 40$. The ambiguity of doxa - the struggle for Being against seeming $\left(78 / \mathrm{II}_{3}\right)$

\$4I. The poetic shaping of the struggle between Being and seeming among the Greeks (8I/II6)

$\$ 42$. The belonging of seeming to Being as appearing. Errancy as the interlocking of Being, unconcealment, and seeming (82/II9)

$\$ 43$. Thinking in the inception of philosophy (Parmenides) as the opening up of the three paths: to Being and into unconcealment, to not-Being, to seeming (83/120)

$\$ 44$. The inner connection between the separations "Being and seeming" and "Being and becoming" (87/126)

\section{Being and Thinking}

$\$ 45$. The preeminence of this distinction and its historical meaning $(88 / \mathrm{I} 28)$

\$46. The definition of "thinking." Thinking as re-presenting $(90 / 130)$

$\$ 47$. "Logic" and its provenance (91/132)

$\$ 48$. The original meaning of logos and legein (94/135)

$\$ 49$. The demonstration of the inner connection between logos and phusis in the inception of Western philosophy. The concept of logos in Heraclitus (96/139)

\$50. The inner necessity and possibility of the separation of phusis and logos on the basis of their original unity. Logos in Parmenides and the "primal statement" (IO3/I5O) 
\$5r. The determination of human Being on the basis of the essence of Being itself in the saying of Parmenides: the happening of the essential belonging-together of Being and apprehending (106/155)

\$52. Thinking poetry as the essential opening of human Being. Interpretation of the first choral ode of Sophocles' Antigone in three phases (110/160)

a) The first phase: the inner contour of the essence of the uncanniest, the domains and the extent of its sway and its destiny (II4/I65)

b) The second phase: the development of the Being of the human being as the uncanniest (II7/I70)

c) The third phase: authentic interpretation as the saying of the unsaid. The Being-here of historical humanity as the breach for the opening up of Being in beings - the incident (I23/I80)

$\$ 53$. The renewed interpretation of the saying of Parmenides in the light of Sophocles' choral ode: the belonging together of noein and einai as the reciprocal relation of techne and $d i k \bar{e}$. Unconcealment as uncanniness. Apprehending as decision. Logos as urgency and as ground of language (I26/184)

\$54. The inceptive interpretation of the essence of humanity as phusis = logos anthroppon echōn in contrast to the later formula: anthrōpos = zōon logon echon (133/194)

\$55. The disjunction of logos and phusis and the priority of logos to Being. Logos becomes a court of justice over Being, phusis becomes ousia (136/198)

a) Phusis becomes idea: idea as essential consequence becomes the essence itself. Truth becomes correctness. Logos becomes apophansis and the origin of the categories (137/200)

b) The basis for the change of phusis and logos into idea and assertion: the collapse of unconcealment - the inability to ground alêtheia in the urgency of Being (I44/2II) 
\$56. Indication of the happening of the collapse of unconcealment in its historical course: the conversion of truth into "correctness" in the wake of the establishment of the truth of ousia (I46/213)

\section{Being and the Ought}

\$57. The ought as the opposite of Being inasmuch as Being determines itself as Idea. Development and completion of the opposition. The philosophy of values (I49/219)

\$58. Summary of the four distinctions with regard to the stated seven points of orientation ( $152 / 222)$

a) The fundamental character of Being that runs through the four separations: constant presence, on as ousia (153/224)

b) The question concerning Being in contrast to Nothing as the first step toward truly overcoming nihilism ( $154 / 226)$

c) The necessity of a new experience of Being in the full breadth of its possible essence. The transformation of Being, as encircled by the four separations, into the encompassing circle and ground of all beings: the distinction between Being and beings as the original separation ( $155 / 226)$

\$59. The essence of the human being (Being-here) as the site of Being. "Being and time": time as the perspective for the interpretation of Being ( $157 / 229$ ) 